\title{
Heritability Studies of Yield and Yield Associated Traits in Wheat Genotypes
}

\author{
Jalal A. Al-Tabbal (Corresponding author) \\ Department of Applied Science, Al-Huson University College \\ Al-Balqa`Applied University, Al-Huson, Jordan \\ Tel: 962-79-766-0137_E-mail: Jaltabbal@bau.edu.jo
}

Ahmad H. Al-Fraihat

Department of Applied Science, Ajloun University College

Al-Balqa`Applied University, Ajloun, Jordan

Received: September 8, 2011

Accepted: September 28, $2011 \quad$ Online Published: February 2, 2012

doi:10.5539/jas.v4n4p11

URL: http://dx.doi.org/10.5539/jas.v4n4p11

This study has been financed by Al-Balqa Applied University.

\begin{abstract}
This study was conducted to evaluate the performance of twenty three promising wheat genotypes and one indigenous cultivar over two years for yield and quality characteristics in order to assess the presence of variability for desired traits and a significant amount of variation for different parameters. Genetic parameters, correlations, and partial regressions were estimated for all the traits. Analysis of variance revealed significant differences among the genotypes for all the characters. The estimates of genotypic coefficient of variation (GCV) and phenotypic coefficient of variation (PCV) were high for grain yield per plant, plant height, biological yield and kernel weight and number of kernel per main spike. Broad sense heritability $\left(\mathrm{H}^{2}\right)$ estimates for various traits ranged from $50-100 \%$. Grain yield per plant showed highly significant positive genetic and phenotypic correlation with kernel weight, number of kernels per main spike and number of spikelet's per main spike. The total variability calculated through multiple correlation in the population for yield improvement accounted by fertile tiller number and kernel weight of main spike was $78.6 \%$ compared to $82.4 \%$ accounted by the all characters. It is concluded that more fertile tiller number and kernel weight of main spike are major yield contributing factors in selecting high yielding wheat cultivars.
\end{abstract}

Keywords: Genotypic, Heritability, Phenotypic, Wheat, Yield

\section{Introduction}

Durum wheat (Triticum durum) is one of the most widely cultivated and important food crop in the world ( Nachit et al., 1998). The world production of wheat increased by 13\% during the period 1994 to 2007, while in Jordan, wheat production decreased by 55\% (FAO, 2009). Different methods could be used to increase cereal production, such as increasing area of production, effective cultural practices, and improved varieties (Cassman, 1999). In Jordan, as land is limited and most of the production area is under semi-arid conditions, developing high yielding varieties adapted to local conditions could be employed, understanding the magnitude of existing variability, proper characterization of the most important physiological traits and their interrelationships with yield and yield components would be extremely helpful in the synthesis of most efficient and highly productive genotypes (Joshi et al., 1982). So, cereal crop improvement depends on the continuous supply of new germplasm material as donors of various genes of agronomic importance. The development of high yielding wheat cultivars is the main objective of any breeding programs in the world (Ehdaie and Waines, 1989). Identification of better genotypes with desirable traits and their subsequent use in breeding program and establishment of suitable selection criterion can helpful for successful varietals improvement program. Analysis of variability among the traits and the association of a particular character in relation to other traits contributing to yield of a crop would be great importance in planning a successful breeding program (Mary and Gopalan, 2006). Development of 
high-yielding varieties requires a thorough knowledge of the existing genetic variation for yield and its components. The observed variability is a combined estimate of genetic and environmental causes, of which only the former one is heritable. However, estimates of heritability alone do not provide an idea about the expected gain in the next generation, but have to be considered in conjunction with estimates of genetic advance, the change in mean value between generations (Shukla et al., 2006). One of the main objectives of any breeding program is to produce high yielding and better quality lines for release as cultivars to farmers. The prerequisite to achieve this goal is to find sufficient amount of variability, in which desired lines are to be selected for further manipulation to achieve the target. Introduction of new populations can be made from one region to the other easily and may be used for further manipulation to develop breeding lines (Jamal et al., 2009). Durum wheat germplasm introduced from International Center for Agricultural Research in the Dry Areas (ICARDA) is annually evaluated under rainfed conditions (Mohammadi et al., 2007). The genotypes out yielding the checks are selected to be evaluated in advanced yield trials in the subsequent seasons to confirm their superiority. Adaptability and yield stability of the outstanding genotypes are tested in the national uniform yield trials and in farmer's fields, and the best ones are proposed for release, after being evaluated for their grain yield and quality. The present study was conducted to evaluate the performance of twenty three promising wheat genotypes and one indigenous cultivar in order to assess the presence of variability for desired traits and a significant amount of variation for different parameters.

\section{Materials and Methods}

\subsection{Plant Materials}

Twenty three promising new genotypes from the International Center for Agricultural Research in the Dry Areas (ICARDA) were used. Omrabi 5 (entry no. 2), Haurani (entry no. 7), Korifla (entry no. 11), Waha (cham 1, entry no. 16) and Gidara- 2 ( entry no. 20) are the checks. Entry number 24 was reserved for local check (Acsad). Entry names and pedigree appear in Table 1.

\subsection{Field Experimental Setup}

The genotypes were sown in the first week of December 2005 and the second week of December 2006 at Al AlBalqa' Applied University -Al-huson Field Campus in a randomized complete block design with three replications. The experimental plots consisted of 6 rows of $2.5 \mathrm{~m}$ length with $30 \mathrm{~cm}$ spaces and they were sown by hand. The seed rate of $133 \mathrm{~kg}$ per hectare and recommended dose of fertilizer (100:70:50, NPK) $\mathrm{kg}$ per hectare were applied. Weeds were removed by hand prior to flowering stage. Standard cultural practices were followed for raising the crop.

\subsection{Weather Conditions}

The precipitation and average temperature for the 2005-2006 and 2006-2007 cropping seasons in Al-huson Field Campus are presented in Table 2. Total precipitation in 2005- 2006 was $261.8 \mathrm{~mm}$, while it was $276.8 \mathrm{~mm}$ in 2007-2008.

\subsection{Characters Studied}

\subsubsection{Phenotypic Parameters Estimates}

The characters measured were biological yield pert plant (g) (BY), grain yield per plant (g) (GY), plant height $(\mathrm{cm})(\mathrm{PH})$ (measured from the base of the plant to the tip of the plant at the time of physiological maturity), tillers per pant (TN) (recorded by counting the number of tillers per plant selected at random), number of fertile tillers (FTN), number of kernels per main spike (KN), number of spikelet per main spike (Sp), kernel weight of main spike (g) (KW), Number of days to heading (HD) (counted from the date of sowing to the date on which approximately $50 \%$ tillers produced spikes.), number of days to maturity (MD) (calculated when the plants were physiologically mature (the stage when color of plant changes from green to golden yellow and its tillers can break easily with hands)), grain filling period (GFP). From these measurements, estimates of harvest index using Eq. 1 were also computed and analyzed.

$$
H I=G Y / B Y
$$

\subsubsection{Genetic Parameters Estimates}

Heritability in broad sense $\left(\mathrm{H}^{2}\right.$ or $\mathrm{h}^{2)}$ was estimated according to Falconer (1989) using eq. 2:

$$
h 2=\frac{\sigma 2 \mathrm{~g}}{\sigma 2 \mathrm{ph}}
$$


$h$ 2: Heritability; $\sigma 2 \mathrm{~g}$ : genotypic variance and $\sigma 2 \mathrm{ph}$ : phenotypic variance. Genotypic $(\sigma 2 \mathrm{~g})$ and Phenotypic $(\sigma 2 \mathrm{ph})$ were obtained from the analysis of variance table according to Comstock and Robinson (1952) using eq. 3 and eq. 4 :

$$
\begin{aligned}
& \sigma 2 \mathrm{~g}=\frac{\mathrm{MS} 1-\mathrm{MS} 2}{\mathrm{r} \times \mathrm{s}} \\
& \sigma 2 \mathrm{ph}=\frac{\mathrm{MS} 1}{\mathrm{r} \times \mathrm{s}}
\end{aligned}
$$

(Where r: replication, s: season MS1: Mean square for cultivar, MS2: Mean square for cultivar×season).

The mean values were used for genetic analyses to determine Phenotypic Coefficient of Variation (PCV) and Genotypic Coefficient of Variation (GCV), according to Singh and Chaudhury (1985) using eq. 5 and eq. 6:

$$
\begin{aligned}
& \operatorname{GCV}(\%)=\frac{\sqrt{\sigma 2 g}}{x} * 100 \\
& \operatorname{PCV}(\%)=\frac{\sqrt{\sigma 2 p h}}{x} * 100
\end{aligned}
$$

Where:

$\sigma 2 \mathrm{~g}=$ genotypic variance.

$\sigma 2 \mathrm{ph}=$ phenotypic variance.

$X=$ sample mean.

Genetic advance (GA) was calculated with the method suggested by Allard (1960); Singh and Chaudhary (1979) using eq. 7 :

$$
G A=k . \sigma p h . h 2
$$

Where

GA: genetic advance.

$\mathrm{K}:$ constant $=2.06$ at $5 \%$ selection intensity.

$\sigma p h$ : square root of phenotypic variance .

$h$ 2: Heritability.

$$
\text { GA as } \% \text { of mean }(\mathrm{GAM})=(\mathrm{GA} / \text { mean value }) * 100
$$

Phenotypic and genotypic correlations were estimated using the standard procedure suggested by Miller et al. (1958) and Kashiani and Saleh (2010) from the corresponding variance and covariance components using eq. 9 and eq. 10 :

Phenotypic correlation coefficient

$$
r p x y=\frac{\sigma p x y}{\sqrt{\sigma 2 p \mathrm{p} * \sigma 2 \mathrm{py}}}
$$

Genotypic correlation coefficient

$$
r g x y=\frac{\sigma g x y}{\sqrt{\sigma 2 g x * \sigma 2 g y}}
$$

Where, $\boldsymbol{r}$ pxy $=$ phenotypic correlation coefficient between character $\mathrm{X}$ and $\mathrm{Y}$ and $\boldsymbol{r} g x y=$ Genotypic correlation coefficients between character $\mathrm{X}$ and $\mathrm{Y}$.

\subsection{Statistical Analysis}

Analysis of variance, using completely randomized block design, was computed for all the characters evaluated using the computer software system of SAS (SAS Institute Inc., 2002).

\section{Results and Discussion}

\subsection{Phenotypic Variation}

The results from analyses of variance over two years for the investigated characteristics are presented in Table 3 . In this experiment, grain yield and some grain quality characteristics of the twenty three promising wheat 
genotypes and one indigenous cultivar (Acsad) which were introduced from ICARDA were assessed in a two year study and a high significant variability among the promising wheat genotypes were determined with respect to the studied parameters (Table 4). Due to genotypic variations of the genotypes included in the investigation, their responses significantly differed (5\%). Such considerable range of variations provided a good opportunity for yield improvement. Effects of cultivar $(\mathrm{V})$ and year $(\mathrm{Y})$ were found to be significant for all the parameters, except the effect of year for grain yield per plant, kernel weight of main spike and grain filling period. However, $\mathrm{Y} \times \mathrm{V}$ was not significantly differed. The mean values of the characteristics studied were shown in Table 5 .

\subsection{Promising Wheat Genotypes VS Standard Cultivar (Acsad)}

Comparisons between the promising wheat genotypes and the improved cultivar revealed that, in general, the local check cultivar were heavier in biological yield, grain yield, number of spikelet per main spike (Sp) and number of kernel per main spike (KN)

Also, the local check was later in maturity time and had longer period of grain filling.

The mean values of other characters compared to the local check cultivar are presented in Table 5. There was one promising wheat genotype (Entry no. 19) superior to the local check Acsad for grain yield per plant. The grain yield and other characters of the superior plant and check variety is presented in Table 6. Among yield components, this genotype was better than the check in kernel number and kernel weight.

\subsection{Genetic Variability}

In trying to determine the extent to which variation in yield components are responsible for differences in yield among various cultivars, it must be borne in mind that overall variability depends on heritable and non-heritable components. While coefficients of variation measure the magnitude of variability present in a population, estimates of heritability and genetic advances are important preliminary steps in any breeding program as they provide information needed in designing the most effective breeding program and the relative practicability of selection. Genotypic variance, phenotypic variance, genotypic coefficient of variability (GCV), phenotypic coefficient of variability (PCV), broad sense heritability, genetic advance and genetic advance expressed as percentage of mean for twelve characters are presented in Table 7.

\subsection{Estimates of Genotypic and Phenotypic Coefficients of Variation}

The results revealed considerable phenotypic and genotypic variances among the genotypes for the traits under consideration. In all traits a large portion of the phenotypic variance was accounted for by the genetic component except for harvest index and number of fertile tiller per plant in which the contributions of genetic variance to phenotypic variance were only 50 and $58.3 \%$, respectively. Generally, 50 to $100 \%$ of the observable variability was due to the genetic variation. This is an indication for the existence of immense inherent variability that remains unaltered by environment conditions among the genotypes, which in turn is more useful for exploitation in selection and hybridization programs. The estimates of GCV were high for grain yield per plant (23.876), plant height (27.651), biological yield and kernel weight (18.538) and number of kernel per main spike (15.419) . The remaining traits recorded moderate to low GCV estimates. The PCV values were higher than GCV values for all the traits which reflect the influence of environment on the expression of traits.

\subsection{Estimates of Heritability in Broad Sense}

Although the genotypic coefficient of variation revealed the extent of genetic variability present in the genotypes for various traits, it does not provide full scope to assess the variation that is heritable. The genotypic coefficient of variation along with heritability estimates provide reliable estimates of the amount of genetic advance to be expected through phenotypic selection (Burton, 1952). The results of the present study indicated that moderate heritability values were recorded for number of productive tillers per plant, number of tillers per plant and harvest index. The high heritability estimates in characters like kernel weight of main spike, grain yield per plant, number of kernel per main spike, biological yield per plant, number of spikelet per main spike, plant height, maturity date, heading date, and grain filling period indicated a high response to selection in these traits. High heritability estimates for grain yield, number of spikelets per spike, number of seeds per spike, plant height, 100-seed weight and number of tillers per plant were also reported (Riaz-Ud-Din, et al., 2010; Sachan and Singh, 2003 ; Siddique et al, 2006 ; Ali et al., 2008; Adewale et al ., 2010; Rahim et al, 2010) which support the present findings.

\subsection{Estimates of Expected Genetic Advance}

Heritability and genetic advance are important selection parameters. The estimate of genetic advance is more useful as a selection tool when considered jointly with heritability estimates (Johnson et al., 1955). The estimates 
of genetic advance help in understanding the type of gene action involved in the expression of various polygenic characters. High values of genetic advance are indicative of additive gene action whereas low values are indicative of non-additive gene action (Singh and Narayanan, 1993). Thus the heritability estimates will be reliable if accompanied by high genetic advance. The expected genetic advance values for twelve characters of the genotypes evaluated is presented in Table 7.These values are also expressed as percentage of the genotypes mean for each character so that comparison could be made among various characters, which had different units of measurement. High heritability along with high genetic advance is an important factor for predicting the resultant effect for selection the best individuals. In the present investigation, High heritability accompanied with high genetic advance as percent of the mean in case of kernel weight of main spike, grain yield per plant, number of kernel per main spike, biological yield per plant, number of spikelet per main spike and plant height indicates that these are simply inherited traits and most likely the heritability is due to additive gene effects and selection may be effective in early generations for these traits. Similar findings have been reported by Dwivedi et al., 2002; Sharma and Garg (2002); and Ali et al., 2008. High heritability for maturity date, heading date, number of fertile tillers per plant and harvest index coupled with low genetic advance indicates non-additive gene effects. Therefore, there seems a limited scope for improvement in this trait. From the above discussion, kernel weight of main spike, grain yield per plant, number of kernel per main spike, biological yield per plant, number of spikelet per main spike and plant height were shown to have high to moderate genotypic variance, high to moderate heritability and greater genetic gain. Selection can therefore be based on these characters and their phenotypic expression would be a good indicator of their genotypic potentiality. The remaining traits recorded lower scores in the three genetic parameters considered in this study and therefore offered less scope for selection as they were much more under the influence of the environment.

\subsection{Genotypic and Phenotypic Correlation among Characters}

The phenotypic and genotypic correlations for morpho-agronomic traits are presented in Table 8. An understanding of inter-character correlation is essential to successful selection of useful genotypes from the whole population but intensive selection for any characteristic might result in losses in others (Lebsock and Amaya, 1969). Genotypic correlation coefficient values were greater for most of the characters than their corresponding phenotypic correlation coefficient values, indicating inherent association of the characters. Thousands kernel weight and number of kernels per main spike which are the main two components of grain yield, gave the highest positive significant phenotypic and genotypic association with grain yield per plant, implying that improving one or the two characters could result in high grain yield. Since yield of grain is the product of number of spikes, number of kernels per spike, and kernel weight, all assume importance in efforts to attain new levels of productivity in wheat. Yield per plant had highly significant and positive phenotypic and genotypic correlations with number of spikelet per main spike. Number of productive tillers per plant had a highly significant phenotypic correlation with grain yield but had low genotypic correlation. The significant positive correlation of tillers per plant with yield per plant have been reported by Mondal et al., (1997) and that of number of grains per spike and number of spikelets per spike by Raut et al., (1995). Physio-morphological trait i.e plant height ranked the second after yield components and tiller number in their positive associations with grain yield. Positive significant associations were obtained between grain yield and plant height because these tall lines generally excelled in their capacity to support kernel growth by stem reserve mobilization (Blum et al., 1989). Therefore, selection for tall plant tends to increase grain yield per plant. A positive association between grain yield and grain filling period was obtained. These results agree with results obtained by Gebeyehou et al., (1982). On the contrary, grain yield had strong negative correlation $(\mathrm{P}<0.01)$ with days to heading, suggesting that selecting early heading genotypes with long grain filling period would give high grain yield under moisture stress area. Similar results were found by Amin et al. (1992), Oosteron and Acevedo (1992) and Gashaw (2007), who reported that early heading genotypes with adequate grain filling period escape terminal moisture stress and, thus give better grain yield. The yield components exhibited varying trends of association among themselves. Plant height showed negative and significant to highly significant genotypic correlations with number of productive tillers per plant, number of grains per spike and positive significant correlations with kernel weight per main spike. The significant positive correlation of plant height with kernel weight and the negative correlation with productive tillers per plant and number of grains per spike have been reported by Ali et al. (2008). Number of grains per spike had strong negative association with plant height and strong positive association with number of spikelets per spike which agree with Ali et al. (2008).

\subsection{Multiple Correlation and Regression Analysis}

In order to determine the effect of morphological traits on grain yield, multiple correlation analyses were carried out (Table 9). The joint association through multiple correlations of all characters studied with yield was highly 
significant. The highly significant multiple correlations of characters $(0.886)$, via. fertile tiller number and kernel weight of main spike, with grain yield was found close to the multiple correlation of all characters $(0.901)$. To evaluate the correlation between variables, it is important to know this "magnitude" or "strength" as well as the significance of the correlation. It expresses the amount of common variation between the two variables. The coefficient of determination $\left(\mathrm{R}^{2}\right)$ indicated that the total variability accounted by all the characters considered together was $82.4 \%$, whereas $78.6 \%$ of the total variability for yield per plant could be accounted if selection was based only on fertile tiller number and kernel weight of main spike. Thus these two traits were the key contributors to yield per plant in this study. The findings of this study are almost consistent with the results obtained by Naserian et al 2007. The significance of partial regression coefficients was also tested (Table 10). Partial regression analysis of grain yield on the basis of all yield components are given in Table 10a. Yield showed highly significant partial regression coefficient with kernel weight of main spike (1.28) and fertile tiller number (0.964). The selection of best regression equation done through backward elimination procedure revealed that kernel weight of main spike and fertile tiller number were the most effective variables contributing to the grain yield. The partial regression coefficients of kernel weight of main spike (1.39) and fertile tiller number (0.839) were highly significant (Table $10 \mathrm{~b}$ ). The best regression equation to bring the maximum improvement in the grain yield has been shown in eq. 11 .

$$
Y=-1.216+0.839 \times 1+1.392 \times 4
$$

Where, $\mathrm{x} 1$ : Fertile tiller number, $\mathrm{x} 4$ : Kernel weight of main spike.

For yield, $78.59 \%$ of total variability could be taken into account if the selection is based on the kernel weight of main spike and fertile tiller number. Thus, indicating that more emphasis should be laid on the improvement of these two components for increasing the grain yield in wheat.

\section{Conclusions}

The present study revealed that grain yield per plant had strong and positive genotypic correlation with fertile tiller number and kernel weight of main spike. Multiple correlations indicated that the total variability accounted by these traits was $78.6 \%$. Regression analysis also indicated fertile tiller number and kernel weight of main spike as the most effective variables contributing to the grain yield. So, it is concluded that these two traits may be considered as the selection criteria for the improvement of grain yield.

\section{Acknowledgement}

The author appreciated the International Center for Agricultural Research in the Dry Areas (ICARDA) and Al-Balqa Applied University for the support extended to this investigation.

\section{References}

Adewale, B.D., Okonji,C., Oyekanmi, A. A., Akintobi, D.A.C., \& Aremu, C.O. (2010). Genotypic variability and stability of some grain yield components of Cowpea. Afr. J. Agric. Res., 5 (9), 874-880.

Ali, Y., Atta, B.M., Akhter, J., Monneveux, P., \& Lateef, Z. (2008). Genetic variability, association and diversity studies in wheat (Triticum aesitum L.) germplasm. Pak. J. Bot., 40(5), 2087-2097.

Allard, R.W. (1960). Principles of plant breeding. John Wiley and Sons, New York.

Amin, M.R., Barma, N.C., \& Razzague, M.A. (1992). Variability, heritability, genetic advance and correlation study in some quantitative characters in durum wheat. Rachis., 1(2), 30-32.

Blum, A., Golan, G., Mayer, J., Sinmena, B., Shpiler, L. \& Burra, J. (1989). The Drought Response of Landraces of Wheat from the Northern Negev Desert in Israel. Euphytica, 43, 87-96.

Burton, N.W. (1952). Quantitative inheritance in grasses. Proc.Intl. Grassland Congr., 1, 277-283.

Cassman, K.G. (1999). Ecological intensification of cereal production systems: Yield potential, soil quality, and precision agriculture. Proc. Natl. Academy of Science., 96, 5952-5959.

Comstock, R. R., \& Robinson, H. F. (1952). Genetic parameters, their estimation and significance, proc. $6^{T H}$ international Grassland Congress. Vol. 1, Nat. Publ. co. Wash., D.C., U.S.A.Dwivedi, A.N., Pawar, I. S., Shashi, M., \& Madan, S. (2002). Studies on variability parameters andcharacter association among yield and quality attributing traits in wheat. Haryana Agric. Univ.J. Res., 32(2), 77-80.

Ehdaie, B., \& Waines, J. G., (1989). Genetic variation, heritability and path analysis in land races of bread wheat from South Western Iran. Euphytica., 41, 183-190. 
Falconer, D.S. (1989). Introduction to Quantitative Genetics. ( ${ }^{\text {rd }}$ Ed). Logman Scientific and Technical, Logman House, Burnt Mill, Harlow, Essex, England.

FAO. (2009). Food and agriculture organization of the united nations, In : FAO Statistical Yearbook, Rome, Italy.

Gashaw, A., Hussein, M., \& Harjit, S. (2007). Selection criterion for improved grain yields in ethiopian durum wheat genotypes. ACSJ., 15, $25-31$.

Gebeyehou, G., Knott, D.R., \& Baker, R.J. (1982). Rate and duration of grain filling in durum wheat cultivars. Crop Sci., 22, 337-340.

Jamal, Khalil, I. H., Bari, A., Sajid Khan., \& Zada, I. (2009). Genetic variation for yield and yield components in rice. ARPN J. Agril. Biol. Sci., 4:6: 60-64.

Johnson, H.W., Robinson, H. E., \& Comstock, R. E. (1955). Estimates of genetic and environmental variability in soybean. Agron. J., 47, 314-318.

Joshi, A.K., Sharma, G. S., \& Dhari, R. (1982). Variability and association of flag leaf area and other trait in wheat. Indian. J. Agric. Sci., 52 (6): 351-355.

Kashiani, K., \& Saleh, G. (2010). Estimation of genetic correlations on sweet corn inbred lines using SAS Mixed Model. AJABS, 5 (3), 309-314.

Lebsock, K. L., \& Amaya, A. (1969). Variation and covariation of agronomic traits in durum wheat. Crop Sci., 9, 372-375.

Mary, S.S., \& Gopalan, A. (2006). Dissection of genetic attributes yield traits of fodder cowpea in $\mathrm{F}_{3}$ and $\mathrm{F}_{4} . J$. Applied Sci. Res., 2(10), 805-808.

Miller, P.A., Williams, J. C., Robinson, H. F., \& Comstock, R. E. (1958). Estimates of genotypic and environmental variances and covariances in upland cotton and their implications in selection. Agron J., 50, 126-131.

Mohammadi, R., Abdulahi,A., Haghparast, R. \& Armion, M. (2007). Interpreting genotype $\times$ environment interactions for durum wheat grain yields using nonparametric methods. Euphytica, 157, 239-251.

Mondal, A.B., Sadhu, D. P. \& Sarkar, K. K. (1997). Correlation and path analysis in bread wheat. Enviroment and Ecology, 15(3), 537-539.

Nachit, M. M., Baum, M., Poreciddu, E., Monneveux, P., \& Picard, E. (1998). SEWANA (South Europe, West Asia and North Africa) durum research network. Proceeding of the SEWANA Durum network workshop, Mar. 20-23, ICARDA, Aleppo, Syria, pp: 361-361.

Naserian, B., Asadi, A. A., Rahimi, M., \& Ardakani M. R. (2007). Evaluation of wheat cultivars and mutants for morphological and yield traits and comparing of yield components under irrigated and rain fed conditions. Asian J. Plant sci., 6(2), 214-224.

Oosteron, E. J., \& Acevedo, E. (1992). Adaptation of barley (Hordeum vulgare L.) to harsh Mediterranean environments. Euphytica., 62, 29-38. http://dx.doi.org/10.1007/BF00036084

Rahim, M.A., Mia, A. A., Mahmud, F., Zeba, N., \& Afrin, K. S. (2010). Genetic variability, character association and genetic divergence in Mungbean (Vigna radiataL. Wilczek). POJ., 3(1), 1-6.

Raut, S.K., Manjaya, J. G., \& Khorgade, P. W., (1995). Selection criteria in wheat (Triticum aestivum L.). PKV Res., 19(1), 17-20.

Riaz-Ud-Din., Subhani, G. M., Ahmad. N., Hussain, M., \& UR Rehman, A., (2010). Effect of temperature on development and grain formation in spring wheat. Pak. J. Bot., 42(2), 899-906.

Sachan, M.S., \& Singh, S. P. (2003). Genetics of yield and its components in durum wheat (Triticum durum Desf.). J. Interacademicia, India, 7(2), 140 -143.

SAS Institute. (2002). SAS user's guide: Statistics version 9 for windows. SAS Institute., Carry, NC.

Sharma, A. K., \& Garg, D.K. (2002). Genetic variability in wheat (Triticum aestivum L.) crosses under different normal and saline environments. Annals Agric. Res., 23(3), 497- 499.

Shukla, S., Bhargava, A., Chatterjee, A.,Srivastava, A., \& Singh, S. P. (2006). Genotypic variability in vegetable amaranth (Amaranthus tricolor L.) for foliage yield and its contributing traits over successive cuttings and years. Euphytica., 151, 103-110. http://dx.doi.org/10.1007/s10681-006-9134-3 
Siddique, M., Faisal, M., Malik, A., \& Awan, S. I. (2006). Genetic divergence, association and performance evaluation of different genotypes of mungbean (Vigna radiata). Int. J Agri. Biol., 8(6), 793-795.

Singh, P., \& Narayanan, S. S. (1993). Biometrical techniques in plant breeding. Kalyani, Publishers. New Delhi, India.

Singh, R. K. \& Chaudhary, B. D. (1985). Biometrical methods in quantitative analysis. Kalyani, Publishers. New Delhi New Delhi, India.

Singh, R. K., \& Chaudhary, B. D. (1979). Biometrical methods in quantitative genetics. Kalyani, Publishers. New Delhi. New Delhi, India.

Table 1. Number, name / cross pedigree, seed source, source number, source number and FAO status of the genotypes

\begin{tabular}{|c|c|c|c|c|c|}
\hline $\begin{array}{l}\text { Entry } \\
\text { No. }\end{array}$ & Name/Cross & Pedigree & $\begin{array}{l}\text { Seed } \\
\text { Source }\end{array}$ & $\begin{array}{l}\text { Source } \\
\text { No. }\end{array}$ & $\begin{array}{l}\text { FAO } \\
\text { Status* }\end{array}$ \\
\hline 1 & Bcr/Gro1//MgnI1 & ICD97-0396-T-1AP-AP-5AP-0AP-14AP-AP & DAT05N & 306 & $\mathrm{U}$ \\
\hline 2 & Mrb5(Check) & & DAT05N & 102 & $\mathrm{D}$ \\
\hline 3 & Adnan-1 & ICD97-0494-T-13AP-AP-5AP-0AP-1AP-AP & DAT05N & 310 & $\mathrm{U}$ \\
\hline 4 & Adnan-2 & ICD97-0494-T-13AP-AP-5AP-0AP-16AP-AP & DAT05N & 312 & $\mathrm{U}$ \\
\hline 5 & Mgnl3/Aghrass2 & ICD99-0015-C-9AP-AP-14AP-AP & DAT05N & 408 & $\mathrm{U}$ \\
\hline 6 & Mgnl3/Aghrass2 & ICD99-0015-C-9AP-AP-21AP-AP & DAT05N & 409 & $\mathrm{U}$ \\
\hline 7 & Hau(Check) & & DAT05N & 107 & $\mathrm{D}$ \\
\hline 8 & Src2/Azn1 & ICD99-0026-C-17AP-AP-14AP-AP & DAT05N & 410 & $\mathrm{U}$ \\
\hline 9 & Mrf1/Stj2//Bcrch1 & ICD99-0027-C-0AP-14AP-AP-9AP-AP & DAT05N & 504 & $\mathrm{U}$ \\
\hline 10 & Stj3/Dra2/Bcr/3/Ter-3 & ICD99-0036-C-0AP-21AP-AP-9AP-AP & DAT05N & 505 & $\mathrm{U}$ \\
\hline 11 & Krf (Check) & & DAT05N & 111 & $\mathrm{D}$ \\
\hline 12 & Bcrch 1 //Mrf 1 / Stj2 & ICD99-0846-C-0AP-5AP-AP-6AP-AP & DAT05N & 510 & $\mathrm{U}$ \\
\hline 13 & Ter-1//Mrf1 /Stj 2 & ICD99-0866-C-0AP-5AP-AP-5AP-AP & DAT05N & 515 & $\mathrm{U}$ \\
\hline 14 & Mgnl3/Ainzen-1 & ICD98-0043-C-3AP-0AP-8AP-AP-4AP-AP & DAT05N & 604 & $\mathrm{U}$ \\
\hline 15 & Mgnl3/Ainzen-1 & ICD98-0043-C-3AP-0AP-8AP-AP-11AP-AP & DAT05N & 605 & $\mathrm{U}$ \\
\hline 16 & Waha (cham 1, Check) & & DAT05N & 116 & $\mathrm{D}$ \\
\hline 17 & Mgnl 3 /Ainzen-1 & ICD98-0043-C-3AP-0AP-8AP-AP-12AP-AP & DAT05N & 606 & $\mathrm{U}$ \\
\hline 18 & Mgnl 3 /Ainzen-1 & ICD98-0043-C-4AP-0AP-26AP-AP-12AP-AP & DAT05N & 608 & $\mathrm{U}$ \\
\hline 19 & Stj3//Bcr/Lks4/3/Ter-3 & ICD99-0091-T-3AP-AP-6AP-AP & DAT05N & 609 & $\mathrm{U}$ \\
\hline 20 & Gdr2 (Check) & & DAT05N & 120 & $\mathrm{D}$ \\
\hline 21 & Stj3//Bcr/LKs4/3/Ter-3 & ICD99-0091-T-3AP-AP-10AP-AP & DAT05N & 610 & $\mathrm{U}$ \\
\hline 22 & Ter 1/3/Stj3//Bcr/Lks4 & ICD99-1036-T-0AP-2AP-9AP-AP & DAT05N & 622 & $\mathrm{U}$ \\
\hline 23 & Beltagy-2 & ICD97-0396-T-1AP-AP-5AP-0AP-16AP-AP & DAT05N & 821 & $\mathrm{U}$ \\
\hline 24 & Acsad & Local check & & & \\
\hline
\end{tabular}

Note: $\mathrm{U}=$ Undesignated, $\mathrm{D}=$ Designated 
Table 2. Distribution of rainfall and temperature regimes during the seasons

\begin{tabular}{|l|l|l|l|l|}
\hline \multirow{2}{*}{ Month } & \multicolumn{2}{|l|}{ Rainfall $(\mathrm{mm})$} & \multicolumn{2}{l|}{ Temperature ${ }^{\circ} \mathrm{C}$} \\
\cline { 2 - 5 } & $2005 / 2006$ & $2006 / 2007$ & $2005 / 2006$ & $2006 / 2007$ \\
\hline December & 71.1 & 20.8 & 9.85 & 10.12 \\
\hline January & 62.8 & 62.2 & 9.1 & 10.12 \\
\hline February & 87.9 & 102.1 & 11.2 & 11.54 \\
\hline March & 4.5 & 51.3 & 11.65 & 11.64 \\
\hline April & 35.5 & 31 & 15.2 & 14.56 \\
\hline May & 0 & 9.4 & 22.2 & 23.2 \\
\hline June & 0 & 0 & 23.7 & 24.2 \\
\hline Total & 261.8 & 276.8 & & \\
\hline
\end{tabular}

Table 3. Analysis of variance form applied for combined data of two seasons

\begin{tabular}{|l|l|l|l|}
\hline Source of variation & $\mathrm{df}$ & $\mathrm{MS}$ & Expected MS \\
\hline Season (s) & $\mathrm{s}-1$ & - & - \\
\hline Rep. within season & $\mathrm{s}(\mathrm{r}-1)$ & - & - \\
\hline Cultivars (V) & $\mathrm{g}-1$ & $\mathrm{MS} 1$ & $\sigma_{\mathrm{e}}^{2}+\sigma_{\mathrm{gs}}^{2}+\mathrm{sr} \sigma_{\mathrm{g}}^{2}$ \\
\hline $\mathrm{V} \times \mathrm{S}$ & $(\mathrm{s}-1)(\mathrm{g}-1)$ & $\mathrm{MS} 2$ & $\sigma_{\mathrm{e}}^{2}+\mathrm{r}{\sigma_{\mathrm{gs}}}^{2}$ \\
\hline Pooled error & $\mathrm{S}(\mathrm{r}-1)(\mathrm{g}-1)$ & $\mathrm{MS} 3$ & $\sigma_{\mathrm{e}}^{2}$ \\
\hline
\end{tabular}

Table 4a. Analysis of variance for biological yield per plant, grain yield per plant (GY), harvest index $\mathrm{p}(\mathrm{HI})$, tiller number (TN), fertile tiller number (FTN), number of spikelet per main spike (Sp), number of kernel per main spike (KN), kernel weight of main spike (KW), plant height (PH), heading date (HD), maturity date (MD) and grain filling period (GFP) of 24 durum wheat genotypes grown under field conditions

\begin{tabular}{|l|l|l|l|l|l|l|l|l|}
\hline \multirow{2}{*}{ Source of variance } & \multicolumn{7}{|c|}{ Mean square } \\
\cline { 2 - 9 } & BY & GY & HI & TN & FTN & Sp & KN & KW \\
\hline Rep. within season & 13.27 & 00.32 & $00.02^{*}$ & $01.59^{* *}$ & $01.32^{* *}$ & 13.30 & 149.01 & 00.43 \\
\hline Cultivars (V) & $23.24^{* *}$ & $05.33^{* *}$ & $00.01^{* *}$ & $00.43^{* *}$ & $00.36^{*}$ & $20.16^{* *}$ & $342.4^{* *}$ & $02.45^{* *}$ \\
\hline Season (S) & $98.21^{* *}$ & 00.06 & $00.12^{* *}$ & $13.78^{* *}$ & $10.50^{* *}$ & $76.06^{* *}$ & $498.75^{*}$ & 00.25 \\
\hline V $\times$ S & 00.33 & 00.02 & 0.006 & 00.15 & 00.15 & 00.31 & 03.43 & 00.003 \\
\hline Pooled error & 6.17 & 1.51 & 0.006 & 0.232 & 0.219 & 4.76 & 96.16 & 0.43 \\
\hline
\end{tabular}

* Significant at the 0.05 probability level.

Table $4 \mathrm{~b}$. Analysis of variance for biological yield per plant, grain yield per plant (GY), harvest index $\mathrm{p}(\mathrm{HI})$, tiller number (TN), fertile tiller number (FTN), number of spikelet per main spike (Sp), number of kernel per main spike (KN), kernel weight of main spike (KW), plant height $(\mathrm{PH})$, heading date (HD), maturity date (MD) and grain filling period (GFP) of 24 durum wheat genotypes grown under field conditions

\begin{tabular}{|l|l|l|l|l|}
\hline \multirow{2}{*}{ Source of variance } & \multicolumn{4}{|c|}{ Mean square } \\
\cline { 2 - 5 } & PH & HD & MD & GFP \\
\hline Rep. within season & $4399.90^{* *}$ & $149.77^{* *}$ & 1.31 & $161^{* *}$ \\
\hline Cultivars (V) & $1310.66^{* *}$ & $30.98^{* *}$ & $23.7^{* *}$ & $61.79^{* *}$ \\
\hline Season (S) & $13051.12^{* *}$ & $361^{* *}$ & $403.3 * *$ & 1.17 \\
\hline $\mathrm{V} \times \mathrm{S}$ & 47.29 & 2 & 1.39 & 4.49 \\
\hline Pooled error & 32.01 & 5.68 & MD & 5.81 \\
\hline
\end{tabular}

* Significant at the 0.05 probability level. 
Table 5. Variation for 15 characters in 24 durum wheat genotypes and mean values standard check cultivar (Acsad)

\begin{tabular}{|l|l|l|l|l|l|l|l|}
\hline Variable & Range & Mean \pm SE & Std Dev & F. values for genotype & LSD (P-0.05) & CV \% & Acsad \\
\hline BY & $7.98-12.89$ & $10.54 \pm 1.4$ & 1.39 & $3.76^{* *}$ & 1.99 & 19.57 & 012.89 \\
\hline GY & $2.83-05.54$ & $03.94 \pm 0.71$ & 0.66 & $3.53^{* *}$ & 0.99 & 18.01 & 005.08 \\
\hline HI & $0.31-00.44$ & $00.37 \pm 0.04$ & 0.03 & $2.08^{* *}$ & 0.06 & 19.9 & 000.39 \\
\hline TN & $01.91-02.75$ & $02.46 \pm 0.28$ & 0.19 & $1.84 * *$ & 0.39 & 19.58 & 002.75 \\
\hline FTN & $01.75-02.58$ & $02.32 \pm 0.27$ & 0.17 & $1.63 * *$ & 0.38 & 16.15 & 002.33 \\
\hline Sp & $16.00-20.83$ & $17.97 \pm 1.26$ & 1.29 & $4.24 * *$ & 1.75 & 12.1 & 019.92 \\
\hline KN & $38.41-60.08$ & $48.76 \pm 5.66$ & 5.34 & $3.56^{* *}$ & 7.88 & 15.11 & 058.58 \\
\hline KW & $1.69-3.66$ & $02.31 \pm 0.38$ & 0.45 & $5.76^{* *}$ & 0.53 & 18.23 & 003.15 \\
\hline PH & $69-95$ & $0077 \pm 03.26$ & 6.001 & $10.51^{* *}$ & 4.53 & 20.51 & 079.00 \\
\hline HD & $125.83-135.5$ & $131.29 \pm 0.31$ & 3.70 & $5.45^{* *}$ & 2.73 & 1.81 & 132.83 \\
\hline MD & $165.33-172.83$ & $168.23 \pm 0.26$ & 3.12 & $5.43^{* *}$ & 2.39 & 1.24 & 172.83 \\
\hline GFP & $31.16-44.5$ & $36.94 \pm 0.34$ & 4.09 & $10.63 * *$ & 2.76 & 6.52 & 040.00 \\
\hline
\end{tabular}

Table 6a. Mean values of grain yield components of examined genotypes of durum wheat in Al-Huson Field Campus

\begin{tabular}{|l|l|l|l|l|l|l|l|l|}
\hline Entry No. & Name/Cross & BY & GY & HI & TN & FTN & Sp & KN \\
\hline 1 & Bcr/Gro1//MgnI1 & 10.75 & 3.92 & 0.365 & 2.42 & 2.25 & 16.75 & 48.42 \\
\hline 2 & Mrb5(Check) & 11.15 & 4.29 & 0.387 & 2.33 & 2.33 & 18.67 & 50.00 \\
\hline 3 & Adnan-1 & 10.48 & 3.76 & 0.375 & 2.58 & 2.58 & 18.17 & 47.58 \\
\hline 4 & Adnan-2 & 11.79 & 4.21 & 0.356 & 2.75 & 2.42 & 19.42 & 49.33 \\
\hline 5 & Mgnl3/Aghrass2 & 10.46 & 3.66 & 0.347 & 2.67 & 2.50 & 17.75 & 45.33 \\
\hline 6 & Mgn13/Aghrass2 & 10.34 & 4.26 & 0.420 & 2.42 & 2.25 & 17.83 & 51.50 \\
\hline 7 & Hau(Check) & 9.67 & 3.26 & 0.337 & 2.25 & 2.17 & 16.58 & 38.42 \\
\hline 8 & Src2/Azn1 & 8.51 & 3.07 & 0.353 & 1.92 & 1.75 & 19.83 & 46.75 \\
\hline 9 & Mrf1/Stj2//Bcrch1 & 8.77 & 3.39 & 0.382 & 2.50 & 2.42 & 16.33 & 40.25 \\
\hline 10 & Stj3/Dra2/Bcr/3/Ter-3 & 8.23 & 2.90 & 0.355 & 2.50 & 2.33 & 16.67 & 43.42 \\
\hline 11 & Krf(Check) & 11.39 & 4.08 & 0.358 & 2.58 & 2.50 & 18.33 & 45.83 \\
\hline 12 & Bcrch 1//Mrf 1/Stj2 & 7.98 & 2.84 & 0.353 & 2.50 & 2.33 & 16.00 & 45.50 \\
\hline 13 & Ter-1//Mrf1/Stj 2 & 9.27 & 3.52 & 0.380 & 2.42 & 2.17 & 17.50 & 46.58 \\
\hline 14 & Mgn13/Ainzen-1 & 10.04 & 4.12 & 0.418 & 2.42 & 2.33 & 16.83 & 47.83 \\
\hline 15 & Mgn13/Ainzen-1 & 10.86 & 4.15 & 0.386 & 2.67 & 2.50 & 17.67 & 52.58 \\
\hline 16 & Waha (Cham 1, Check) & 9.73 & 3.70 & 0.377 & 2.25 & 2.25 & 18.50 & 51.00 \\
\hline 17 & Mgn1 3/Ainzen-1 & 9.85 & 3.62 & 0.368 & 2.17 & 2.08 & 17.92 & 50.17 \\
\hline 18 & Mgnl 3/Ainzen-1 & 12.05 & 4.98 & 0.418 & 2.42 & 2.33 & 18.42 & 55.92 \\
\hline 19 & Stj3//Bcr/Lks4/3/Ter-3 & 12.74 & 5.54 & 0.443 & 2.50 & 2.33 & 18.75 & 60.08 \\
\hline 20 & Gdr2 (Check) & 12.66 & 3.89 & 0.306 & 2.42 & 2.42 & 20.83 & 53.92 \\
\hline 21 & Stj3//Bcr/LKs4/3/Ter-3 & 11.56 & 4.69 & 0.407 & 2.58 & 2.50 & 19.42 & 51.92 \\
\hline 22 & Ter-1/3/Stj3//Bcr/Lks4 & 10.50 & 3.73 & 0.358 & 2.58 & 2.25 & 17.00 & 40.83 \\
\hline 23 & Beltagy-2 & 11.31 & 4.12 & 0.353 & 2.50 & 2.42 & 16.25 & 48.67 \\
\hline 24 & Acsad & 12.90 & 5.08 & 0.396 & 2.75 & 2.33 & 19.92 & 58.58 \\
\hline
\end{tabular}


Table 6b. Mean values of grain yield components of examined genotypes of durum wheat in Al-Huson Field Campus

\begin{tabular}{|c|l|l|l|l|l|l|}
\hline Entry No. & Name/Cross & KW & PH & HD & MD & GFP \\
\hline 1 & Bcr/Gro1//MgnI & 2.35 & 81 & 128.50 & 168.83 & 40.33 \\
\hline 2 & Mrb5(Check) & 2.50 & 86 & 125.83 & 170.33 & 44.50 \\
\hline 3 & Adnan-1 & 2.07 & 69 & 131.83 & 165.50 & 33.67 \\
\hline 4 & Adnan-2 & 2.44 & 81 & 132.83 & 169.50 & 36.67 \\
\hline 5 & Mgnl3/Aghrass2 & 1.92 & 76 & 131.33 & 168.50 & 37.17 \\
\hline 6 & Mgnl/Aghrass2 & 2.38 & 80 & 132.17 & 168.83 & 36.67 \\
\hline 7 & Hau(Check) & 1.87 & 95 & 131.33 & 171.33 & 40.00 \\
\hline 8 & Src2/Azn1 & 2.35 & 79 & 131.83 & 167.17 & 35.33 \\
\hline 9 & Mrf1/Stj2//Bcrch1 & 1.84 & 72 & 133.83 & 166.50 & 32.67 \\
\hline 10 & Stj3/Dra2/Bcr/3/Ter-3 & 1.69 & 71 & 133.50 & 167.00 & 33.50 \\
\hline 11 & Krf(Check) & 2.20 & 74 & 133.17 & 166.83 & 33.67 \\
\hline 12 & Bcrch 1/Mrf 1/Stj2 & 1.75 & 70 & 134.17 & 165.33 & 31.17 \\
\hline 13 & Ter-1//Mrf1/Stj 2 & 2.32 & 76 & 131.50 & 166.33 & 34.83 \\
\hline 14 & Mgnl3/Ainzen-1 & 2.38 & 72 & 131.33 & 166.50 & 35.17 \\
\hline 15 & Mgn13/Ainzen-1 & 2.29 & 72 & 132.83 & 166.83 & 34.00 \\
\hline 16 & Waha (Check) & 2.17 & 70 & 130.83 & 167.00 & 36.17 \\
\hline 17 & Mgnl 3/Ainzen-1 & 2.20 & 72 & 129.67 & 168.33 & 38.67 \\
\hline 18 & Mgnl 3/Ainzen-1 & 3.06 & 78 & 128.67 & 167.83 & 39.17 \\
\hline 19 & Stj3//Bcr/Lks4/3/Ter-3 & 3.67 & 81 & 127.50 & 168.00 & 40.50 \\
\hline 20 & Gdr2 (Check) & 2.20 & 73 & 135.50 & 171.83 & 36.33 \\
\hline 21 & Stj3//Bcr/LKs4/3/Ter-3 & 2.47 & 80 & 128.67 & 170.33 & 41.67 \\
\hline 22 & Ter-1/3/Stj3//Bcr/Lks4 & 2.04 & 78 & 130.50 & 167.00 & 36.50 \\
\hline 23 & Beltagy-2 & 2.14 & 81 & 130.83 & 169.00 & 38.17 \\
\hline 24 & Acsad & 3.15 & 79 & 132.83 & 172.83 & 40.00 \\
\hline
\end{tabular}

Table 7a. Genetic parameters for some characteristics in wheat genotypes grown during two seasons $2005 / 2006-$ 2007 / 2008 under field conditions

\begin{tabular}{|l|l|l|l|l|l|l|l|l|}
\hline \multirow{2}{*}{ Source of variance } & \multicolumn{9}{|c|}{ Mean square } \\
\cline { 2 - 9 } & BY & GY & HI & TN & FTN & Sp & KN & KW \\
\hline$\sigma_{\mathrm{g}}^{2}$ & 3.818 & 0.885 & 0.001 & 0.047 & 0.035 & 3.308 & 56.495 & 0.408 \\
\hline$\sigma_{\mathrm{ph}}^{2}$ & 3.873 & 0.888 & 0.002 & 0.072 & 0.060 & 3.360 & 57.067 & 0.408 \\
\hline Heritability \% & 98.580 & 99.662 & 50.000 & 65.278 & 58.333 & 98.452 & 98.998 & 100.000 \\
\hline GCV (\%) & 18.538 & 23.876 & 8.546 & 8.812 & 8.063 & 10.121 & 15.419 & 18.538 \\
\hline PCV $(\%)$ & 18.671 & 23.917 & 12.086 & 10.907 & 10.558 & 10.200 & 15.493 & 18.672 \\
\hline GA & 3.997 & 1.933 & 0.046 & 0.364 & 0.294 & 3.719 & 15.391 & 1.316 \\
\hline GAM & 37.925 & 49.072 & 12.449 & 14.785 & 12.680 & 20.698 & 31.564 & 56.962 \\
\hline
\end{tabular}

* Significant at the 0.05 probability level.

Table $7 \mathrm{~b}$. Genetic parameters for some characteristics in wheat genotypes grown during two seasons $2005 / 2006$ 2007 / 2008 under field conditions

\begin{tabular}{|l|c|c|c|c|}
\hline \multirow{2}{*}{ Source of variance } & \multicolumn{4}{|c|}{ Mean square } \\
\cline { 2 - 5 } & PH & HD & MD & GFP \\
\hline$\sigma_{\mathrm{G}}^{2}$ & 210.562 & 4.830 & 3.718 & 9.550 \\
\hline$\sigma_{\mathrm{P}}^{2}$ & 218.443 & 5.163 & 3.950 & 10.298 \\
\hline Heritability \% & 96.392 & 93.550 & 94.127 & 92.736 \\
\hline GCV (\%) & 18.845 & 1.673 & 1.146 & 8.365 \\
\hline PCV (\%) & 19.194 & 1.730 & 1.181 & 8.687 \\
\hline GA & 29.320 & 4.381 & 3.853 & 6.128 \\
\hline GAM & 38.078 & 3.337 & 2.290 & 16.589 \\
\hline
\end{tabular}

* Significant at the 0.05 probability level. 
Table 8. Genotypic (bold) and phenotypic correlations among different quantitative characters in durum wheat genotypes

\begin{tabular}{|c|c|c|c|c|c|c|c|c|c|c|c|c|}
\hline & $\mathrm{BY}$ & GY & $\mathrm{HI}$ & $\mathrm{TN}$ & FTN & $\mathrm{Sp}$ & $\mathrm{KN}$ & KW & $\mathrm{PH}$ & HD & MD & GFP \\
\hline $\mathrm{BY}$ & 1 & $87 * *$ & $0.22 * *$ & $0.43 * *$ & $0.30 * *$ & $0.61 * *$ & $0.72 * *$ & $0.74 * *$ & $0.30 * *$ & $-0.24 * *$ & $0.95 * *$ & $0.71 * *$ \\
\hline GY & $0.84 * *$ & 1 & $7 * *$ & 0.31 ** & $0.04 * *$ & $0.49 * *$ & 0.86 ** & $0.94 * *$ & $0.27 * *$ & $-0.58 * *$ & $.61 * *$ & 0.75 ** \\
\hline $\mathrm{HI}$ & 0.1 & $0.61 * *$ & 1 & $-0.99 * *$ & $-0.99 * *$ & $0.02 * *$ & $0.64 * *$ & $0.75 * *$ & $\mathbf{0 . 0 7} * *$ & $-0.74 * *$ & $-0.19 * *$ & $0.36 * *$ \\
\hline $\mathrm{TN}$ & $0.54 * *$ & $0.38 * *$ & -0.08 & 1 & $0.94 * *$ & $-0.18 * *$ & $0.18 * *$ & 0.14 & $-0.20 * *$ & $0.75 * *$ & $0.29 * *$ & $-0.20 * *$ \\
\hline FTN & $0.58 * *$ & $0.46^{* *}$ & 0.005 & $0.83 * *$ & 1 & $-0.34 * *$ & $0.01 * *$ & -0.27 & $-\mathbf{0 . 5 7} * *$ & $0.49 * *$ & $-0.04 * *$ & $-0.23 * *$ \\
\hline $\mathrm{Sp}$ & $0.59 * *$ & $0.40 * *$ & -0.09 & $0.24 * *$ & $0.26 * *$ & 1 & 0.65 ** & $0.55 * *$ & $0.004 * *$ & 0.17 ** & 0.84 ** & $0.40 * *$ \\
\hline $\mathrm{KN}$ & $0.71 * *$ & $0.71 * *$ & $0.27 * *$ & $0.19 *$ & $0.26 * *$ & $0.59 * *$ & 1 & $0.86 * *$ & $-0.13 * *$ & $-0.32 * *$ & $0.44 * *$ & $0.48 * *$ \\
\hline KW & $0.65 * *$ & $0.82 * *$ & $0.54 * *$ & 0.13 & $0.16^{*}$ & $0.47 * *$ & $0.79 * *$ & 1 & $0.53 * *$ & $-0.55 * *$ & $0.42 * *$ & $0.61 * *$ \\
\hline $\mathrm{PH}$ & $0.40 * *$ & $0.21 *$ & $-0.24 * *$ & $0.27 * *$ & $0.21 * *$ & 0.29 & $0.19 *$ & $0.23 * *$ & 1 & $-0.61 * *$ & $-0.31 * *$ & -0.07 ** \\
\hline HD & $-0.26^{* *}$ & $-0.19^{*}$ & 0.05 & $-0.25 * *$ & $-0.25^{* *}$ & $-0.21 *$ & $-0.22 * *$ & $-0.27 * *$ & $-0.52 * *$ & 1 & $0.21 * *$ & $-0.80 * *$ \\
\hline $\mathrm{MD}$ & $0.18^{*}$ & $0.21 *$ & 0.13 & $-0.22 * *$ & $-0.18^{* *}$ & 0.07 & 0.08 & 0.14 & 0.05 & $0.28 * *$ & 1 & $0.81 * *$ \\
\hline GFP & $0.73 * *$ & $0.34 * *$ & 0.05 & 0.06 & 0.09 & $0.24 * *$ & $0.26^{* *}$ & $0.36 * *$ & $0.51 * *$ & $-0.68 * *$ & $0.5 * *$ & 1 \\
\hline
\end{tabular}

$*, * *$ significance at $5 \%, 1 \%$ level of probability respectively.

Table 9. Multiple correlation analysis of grain yield per plant on the basis of all yield components (Col. 1) and on the basis of fertile tiller number and kernel weight of main spike (Col. 2)

\begin{tabular}{|l|l|l|}
\hline & Col. 1 & Col. 2 \\
\hline Multiple correlation & $0.901 * *$ & $0.886 * *$ \\
\hline Coefficient of determination (R-square) & 0.8241 & 0.7859 \\
\hline Adjusted R-square & 0.8151 & 0.7829 \\
\hline Standard error & 0.4523 & 0.4901 \\
\hline
\end{tabular}

** Significant at $1 \%$ Level

Table 10a. Partial regression analysis of grain yield with its components in wheat genotypes

\begin{tabular}{|l|l|l|l|}
\hline Yield component & Partial regression coefficient (B) & S.E (B) & " $\mathrm{t}$ \\
\hline Fertile tiller number & $0.9641^{* *}$ & 0.09811 & 9.83 \\
\hline Number of spikelet per main spike & -0.0465 & 0.02391 & -1.95 \\
\hline Number of kernel per main spike & 0.0141 & 0.00860 & 1.64 \\
\hline Kernel weight of main spike & $1.2865 * *$ & 0.11189 & 11.49 \\
\hline Plant height & -0.0016 & 0.00547 & -0.30 \\
\hline Heading date & 0.0148 & 0.01342 & 1.11 \\
\hline Maturity date & $0.0545 * *$ & 0.01363 & 4.00 \\
\hline
\end{tabular}

** Significant at $1 \%$ level.

Table 10b. Partial regression analysis of grain yield with fertile tiller number and kernel weight of main spike in wheat genotypes

\begin{tabular}{|l|l|l|l|}
\hline Yield component & Partial regression coefficient (B) & S.E (B) & “ $\mathrm{t}$ ” \\
\hline Fertile tiller number & $0.8391^{* *}$ & 0.0989 & 8.48 \\
\hline Kernel weight of main spike & $1.3921^{* *}$ & 0.0716 & 19.43 \\
\hline
\end{tabular}

** Significant at $1 \%$ level. 